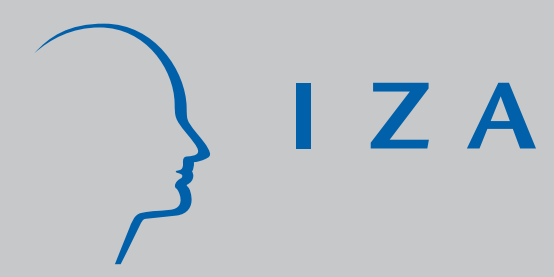

IZA DP No. 1338

Growth, Inequality and Poverty Relationships

Almas Heshmati

October 2004 


\title{
Growth, Inequality and Poverty Relationships
}

\author{
Almas Heshmati \\ Seoul National University, \\ MTT Economic Research and IZA Bonn
}

Discussion Paper No. 1338

October 2004

\author{
IZA \\ P.O. Box 7240 \\ 53072 Bonn \\ Germany \\ Phone: +49-228-3894-0 \\ Fax: +49-228-3894-180 \\ Email: iza@iza.org
}

\begin{abstract}
Any opinions expressed here are those of the author(s) and not those of the institute. Research disseminated by IZA may include views on policy, but the institute itself takes no institutional policy positions.

The Institute for the Study of Labor (IZA) in Bonn is a local and virtual international research center and a place of communication between science, politics and business. IZA is an independent nonprofit company supported by Deutsche Post World Net. The center is associated with the University of Bonn and offers a stimulating research environment through its research networks, research support, and visitors and doctoral programs. IZA engages in (i) original and internationally competitive research in all fields of labor economics, (ii) development of policy concepts, and (iii) dissemination of research results and concepts to the interested public.
\end{abstract}

IZA Discussion Papers often represent preliminary work and are circulated to encourage discussion. Citation of such a paper should account for its provisional character. A revised version may be available directly from the author. 
IZA Discussion Paper No. 1338

October 2004

\title{
ABSTRACT \\ Growth, Inequality and Poverty Relationships*
}

This paper examines the causal relationship between inequality and a number of macroeconomic variables frequently found in the inequality and growth literature. These include growth, openness, wages, and liberalisation. We review the existing cross-country empirical evidence on the effects of inequality on growth and the extent to which the poorest in society benefit from economic growth. The linkage between growth, redistribution and poverty is also analysed. In the review of literature mainly empirical examples from 1990s are taken. In addition we test the conditional and unconditional relationship between inequality and growth in the post World War II period using WIDER inequality database. Regression results suggest that income inequality is declining over time. Inequality is also declining in growth of income. There is a significant regional heterogeneity in the levels and development over time. The Kuznets hypothesis represents a global U-shape relationship between inequality and growth.

JEL Classification: C23, D63, F14, O40, O57

Keywords: growth, openness, income inequality, wage inequality, poverty, indices

\author{
Almas Heshmati \\ Techno-Economic \& Policy Program \\ College of Engineering \\ Seoul National University \\ Bldg \# 38, Room 410 \\ San 56-1, Shilim-dong, Kwanak-gu \\ Seoul 151-742 \\ Korea \\ Email: heshmati@snu.ac.kr
}

\footnotetext{
* An earlier version of this paper was completed while I was working at the World Institute for Development Economic Research, UNU/WIDER. Comments and suggestion from Amit Kumar Bhandari is gratefully acknowledged.
} 


\section{INTRODUCTION}

The world economy grows constantly but the growth pattern can differ over time and among countries. This growth is due to technological change, increased efficiency and capacity in the use of resource and creation of material wealth. Economic downturn, crises and other factors from time to time results in negative growth in certain regions and countries. The East Asian financial crisis and the negative growth of sub-Saharan Africa are the few examples of such development. Large disparities and negative growth rates undermine the integration of the economies and social stability hampering the long-run economic growth.

Several literatures are there investigating the relationship between different combinations of openness, growth, inequality and poverty (Sachs and Werner 1995; Dollar and Kraay 2001a; Person and Tabellini 1994; Deininger and Squire 1998; Goudie and Ladd 1999; van der Hoeven and Shorrocks 2003). In general they found a positive relationship between openness and growth but the differences between and within countries in the impacts of growth on the poor can be large. In recent years the research and debate has focused on the extent to benefit the poor from this economic growth (Ravallion 1998 and 2001; Ravallion and Chen 2003; Ravallion and Datt 2000; Quah 2001). One extreme of the debate argues that the potential benefits of economic growth to the poor are undermined or offset by the inadequate redistributive policies and by increases in inequality that accompany economic growth. The second extreme argues that despite increased inequality in the liberal economic policies and open markets raise incomes of everyone in the society inclusive the poor which proportionally reduce the incidence of poverty. The poor in developing countries often defined as the bottom quintile of the income distribution.

This paper discusses the causal relationship between inequality and the numbers of macroeconomic variables frequently found in the inequality and growth literature are also in relation with pro-poor growth issues. These include growth, openness, wages, liberalisation, etc. ${ }^{1}$ Here the existing cross-country empirical evidence on the inequality effects of growth and the extent to which the poorest in society benefit from economic growth is reviewed. In the review of literature mainly empirical examples from 1990s are taken. In addition we test the conditional and unconditional relationship between inequality and growth post the World War II period based on the WIDER inequality database. The results from the literature will also be compared with those based on the WIID database. Empirical results suggest that the outcomes of policy measures are heterogeneous in their impacts. Economic growth benefits the poor but at the absence of effective redistribution policies which might affect negatively on the income distribution. Several country-specific factors play a significant role in targeting policies to make economic growth pro-poor. Ravallion (2001) expresses the need for deeper micro empirical work on growth and distributional change to identify specific policies to complement growth-oriented policies, and the evaluation of aggregate impacts and their diversity of impacts.

Rest of the paper is organised as follows. Section 2 reviews the growth and convergence. It follows by a discussion of empirical evidence suggesting convergence in growth accompanied by divergence in inequality in Section 3. Section 4 explores the

\footnotetext{
${ }^{1}$ The relationship between income inequality, poverty and globalization is discussed in Heshmati (2003 and 2004a).
} 
linkage between openness and growth to inequality. Section 5 reviews the Kuznets hypothesis. The redistribution of growth is discussed in Section 6. The inequality effects of growth and development is discussed in Section 7 followed by a discussion of wage inequality in Section 8. The other contributing factors are discussed in Section 9. The relationship between growth and inequality based on WIID database is examined in Section 10. The final Section summarises.

\section{GROWTH AND CONVERGENCE}

Most of the work in the growth area use econometric methods to test the hypothesis of income per capita convergence across countries. ${ }^{2}$ Convergence can be absolute or conditional (Barro and Sala-i-Martin 1995; Quah 1996c; Barro 1997; Dowrick and DeLong 2001; and Jones 2002). When the absolute convergence holds a negative relationship between GDP levels and growth rates is observed, implying that the poorer economies are growing faster than the richer countries. Lichtenberg (1994) criticises this practice of testing convergence and suggests the use of variance of productivity over time to test convergence hypothesis. The use of variance neglects the level differences and is probably more appropriate in pooling countries with different initial development.

Conditional convergence refers to the convergence after differences in the steady state across countries which are controlled for. Here in addition to the GDP level (initial income) one controls for other determinants of growth like population growth, education and investment (Mankiew, Romer and Weil 1992). The capital is further decomposed into physical, human and health components in Knowles and Owen (1997) and Heshmati (2000). Health capital is measured as health care expenditure in Heshmati, but Knowles and Owen used life expectancy for measuring it. The growth rate of real per capita GDP is positively related to initial human capital, political stability, physical investment and negatively related to the initial level of real per capita GDP, government consumption and pubic investment (Barro 1991). Benhabib and Rustichini (1996) observed that in reality poor countries have invested at lower rate and have not grown faster than rich countries. The investment rate and growth gaps are persistently increasing.

Despite the numerous bodies of literature and empirics there are still disagreements about the concepts, modelling, estimation of growth and convergence models. The proponents of conditional convergence (Mankiew, Romer and Weil 1992; Barro 1997) find evidence of convergence at the annual 2-5 per cent rate. Bernard and Durlauf (1996) consider convergence as catching up and as equality of long-term forecasts at a fixed time. They show that the cross-section tests developed to test for convergence place much weaker restrictions on the behaviour of growth across countries than time series tests. Many convergence studies are based on the observation of first and last years a country, neglecting the year-to-year variations in its growth rates. Therefore, integration of the two series is commended.

To overcome the problems of losing the year-to-year growth rate variations and valuable information, Islam (1995) uses a dynamic panel data approach and different

\footnotetext{
${ }^{2}$ For an evolutionary growth theory and viewpoint about the process of development and the origin of sustained economic growth see Galor and Moav (2001).
} 
estimators for studying growth convergence producing different results than those obtained in cross-country data. Different forms of inconsistency related to correlated country effects and endogenous explanatory variables and the choice of estimation methods result in per capita income convergence to their steady-state levels at a rate of up to 10 per cent per year (Caselli, Esquivel and Lefort 1996). Nerlove (2000) also found that the conditional convergence rate sensitive to the choice of estimation techniques. Lee, Pesaran and Smith (1997) in their examination of the beta and sigma convergence in stochastic and linearised solution to deterministic Solow growth model observed substantial biases in the rate of convergence due to the ignorance of growth heterogeneity.

Empirical results on more homogenous data show evidences of convergence in income levels and catching up in levels of productivity of OECD (Dowrick and Nguyen 1989). However, convergence in aggregate productivity is not necessarily occurring at disaggregate e.g. industry level. Bernard and Jones (1996) find convergence in some sectors such as services but not manufacturing in 14 OECD countries. Barro and Sala-iMartin (1991) examines the growth and dispersion of personal income and relate the patterns for individual U.S. states to the behaviour of regions focusing on the role of agriculture, manufacturing, transportation and regional concentration. Differences in the within country or between sector growth rates is the main source of within country inequality.

To avoid heterogeneity bias, Bernard and Durlauf (1996) examined homogenous group of OECD countries to reject convergence but found evidence of common trends. Evidence against convergence is also found in Quah (1993) who predicts widening richpoor income disparity. Quah (1996b) finds regional income distribution in Europe to differ across countries and also fluctuate over time. Geographical and national factors are both important for explaining inequality dynamics. Quah (1996c) characterise the feature of cross-country income dynamics as persistence, immobility and polarisation. Lichtenberg (1994) using variance of productivity rejected the convergence among 22 OECD countries. Carree and Klomp (1997) using simulation experiment shows that although countries are relatively homogenous and integrated, test procedure above lead to low probability of accepting convergence in the short period of time.

\section{DIVERGENCE IN EQUALITY}

The empirical finding of convergence in the growth literature is contrary to the evidence of global divergence in the inequality literature (see Quah 1996a). Solimano (2001) explains the puzzle by the conditional convergence requirement that all countries share similar values for the determinants of growth and the same steady state value of longrun income per capita. In his view the strong assumptions of equality of determinant factors whose differences are the core of differential growth performance across countries and international inequality limits the usefulness of conditional convergence. Heterogeneous development has given rise to uneven and complex regional convergence and divergence in GDP per capita and growth rates increases the world inequality which are driven by international or between country inequalities. To narrow global inequality it is required that a sustained acceleration in the rate of economic growth of low and middle income regions combined with the decline in domestic or within country inequality to improve the welfare position of the world's poor. 
It is pointed out by Solimano (2001) that income inequality exploded since the early $19^{\text {th }}$ century. This evolution is essentially due to the increase in inequality among countries or regions of the world. The contribution from the between country component have more impacts on the world distribution of income inequality than the within country component. This is also confirmed by Bourguignon and Morrisson (2002) who find evidence of convergence process among European countries but also divergence among regions and an increasing concentration of world poverty in some regions of the world such as sub-Saharan Africa and South Asia.

At the regional level the dynamics of inequality among eight European countries using LIS data is considered by Iacoviello (1998). He investigates whether inequality converges to a steady state level of income inequality during the process of economic growth and to identify the variables that influences the process of convergence. However, Iacoviella does not reach to a conclusion about the exact nature of the relationship between income and inequality movements. Earlier Quah (1996b) in analysing the regional convergence clusters across Europe found that physical location and geographical spillover matter more for convergence than do macro factors and account for substantial amount of regional income distribution dynamics. Based on a larger sample of 66 countries recently Ravallion (2003) found that within-country income inequalities have been slowly converging since the 1980s. Inequality is tending to fall (rise) in countries with initially high (low) inequality. The speed of convergence was not sensitive to measurement error in the initial inequality measurement. In Epstein and Spiegel (2002) when divergence from acceptable (natural) level of inequality occurs, both lower or higher production levels and economic growth may be expected. The direction of changes is ambiguous.

In sum the empirical findings in the literature, based on large sample of countries and relatively long time period, in general indicate presence of convergence in per capita income, at least among countries with more homogenous development or sharing same regional location, but also significant divergence in income inequality. There is evidence of strong convergence process among more homogenous and integrated European countries and a weak within-country (between-region) convergence among Indian states, divergence among Chinese regions but also divergence among countries or regions of the world. The between-country contribution is much higher then withincountry contribution to the world inequality. Lack of convergence might be explained by various national and global factors such as the absence of regional price indices, infrastructure for development, economic reforms and redistributive policies which affects regions differently.

\section{OPENNESS, GROWTH AND INEQUALITY RELATIONSHIPS}

There are a number of cross-country empirical studies investigating the relationship between openness and growth (see e.g. Edwards 1992 and 1998; Sachs and Werner 1995; Rodriguez and Rodrik 1999; and Dollar and Kraay 2001a and 2001b). In general they find a positive correlation between openness and growth and find that the growth premium of openness tends to decline over time and less beneficial and weaker for the poor countries. On the other hand the results do not indicate the presence of systematic relationship between changes in trade and changes in national inequality. Growing integration of economies and societies around the word is not associated with a higher 
inequality within countries. Trade does not redistribute income among different income groups. Fast growth reduces poverty, but many people living in countries and regions not participating in the integration are falling farther behind reducing their prospects of growing out of poverty. Researchers face methodological difficulties in the measurement of openness and to control for determinants of economic growth and in establishing the causal relationship from openness and integration to growth, inequality and poverty.

There are a number of other studies analysing the relationship between inequality and growth (see e.g. Person and Tabellini 1994; Alesia and Rodirk 1994; Ravallion 1995; and Peroti 1996). A negative relationship between initial inequality in distribution of income and growth is found. However, the findings that more unequal economies grow much slower are not robust due to the reason of data quality and comparability. The negative relationship emerges through the investment in human capital and political channels due to credit rationing (Stiglitz and Weiss 1981) and median voter behaviour (Person and Tabellini 1994). An illustration of the later mechanism on inequality, median voter and redistribution is given in Lee and Roemer (1999). They show that as inequality rises taxation can be less efficient in reducing public spending and redistribution to counteract various forms of inequality in a society.

As several researchers noted above, the reverse linkage between inequality and growth might be indirect. Sylwester (2000) searched to find a transmission mechanism to determine how the change in government policies can lower the negative impact of income inequality on economics growth. In doing so, he explores how income inequality affects spending on public education and how education affects growth. The public education expenditure and growth rates of GDP are jointly estimated by Sylwester. Results based on a cross section of 54 countries for 1970-1985 show that current education expenditures have a negative impact upon contemporaneous growth, but previous expenditures have a positive impact on growth. The negative cost of inequality on growth is found to be only a short-run cost and offset by the long-run positive effects of education.

The effects of education on economic growth can be different. The dual role of human capital, stock of educated workers, as an important determinant of growth and inequality is analysed in Eicher and Garcia-Penalosa (2001). The impact of education on economic growth is through changes in the relationship between skilled and unskilled labours, rate of technical change, labour demand and supply, wages and multiple equilibrium. The relative productivity of skilled to unskilled labour is changing with the rate of technical change. These two types of labour are imperfect substitutes. Their results identify parameters of the demand and supply of labour that are central to the evolution of inequality during the development process. Wolff (2001) using family income current population survey (CPS) data for 1947-1997 finds that the largest effects on income inequality come from equipment investment and unionisation. Investments in equipment increased inequality, while unionisation decreased inequality. Total factor productivity and labour productivity growth and R\&D investment had no effects on inequality.

One major shortcoming of the literature on the link between growth, openness, inequality and poverty is that the causal relationship between these variables has often been neglected. Application of co-integration test and an establishment of linkage and 
direction of causality among the variables of interest will determine whether these relations must be estimated using single equation, recursive or as a system of interdependent equations. Availability of time series data, especially on inequality and poverty, for cross section of countries limits application of this approach. As few examples of such development, Addison and Heshmati (2003) and Gholami, Tom-Lee and Heshmati (2003) tests for causality between foreign direct investment (FDI), GDP growth, trade openness and information and communication technology (ICT). Empirical results based on large samples of industrialised, transition and developing countries suggests that ICT infrastructure and ICT investment increases inflow of FDI to developing countries with implications for their economic growth.

\section{THE KUZNETS HYPOTHESIS}

In addition to welfare, reduction in poverty makes growth strategies important to developing countries. Deininger and Squire (1998) in a different way examine interaction between growth and inequality and investigate how those two factors in turn affect efforts to reduce poverty in the course of economic development which is measured as GDP. The robustness of the inequality-growth relationship is tested by estimation of the following relation:

$$
\begin{aligned}
\text { Growth }_{i t}=\beta_{0} & +\beta_{1} G D P_{i 0}+\beta_{2} G I N I_{i 0}+\beta_{3} I N V_{i t}+\beta_{4} B M P_{i t}+\beta_{5} E D U_{i t} \\
& +\beta_{6} L A N D_{i t}+D_{R}+u_{i t}
\end{aligned}
$$

where $G I N I_{0}$ and $G D P_{0}$ are initial income inequality and $G D P, L A N D$ is land Gini, $I N V$ is investment, $B M P$ is black marker premium, $D$ is regional dummy variables, and $u$ random error term. They use data on Gini index for 108 countries, several of which are observed a number of periods allowing for the construction of country-specific Kuznets curves on the relationship between income inequality and growth:

$$
G I N I_{i t}=\alpha_{i}+\beta_{i} Y_{i t}+\gamma_{i}\left(1 / Y_{i t}\right)+\zeta S+\varepsilon_{i t}
$$

where GINI is Gini coefficient, $Y$ is real per capita income, $S$ is a dummy variable for socialist countries, and $\varepsilon$ random error term.

Three main results emerge from the study by Deininger and Squire. First, there is a strong negative relationship between initial inequality in asset (land) distribution and long-term growth. Second, inequality reduces income growth for the poor, but not for the rich. Third, available longitudinal data provide little support for the temporal relationship as summarised in Kuznets inverted-U hypothesis. ${ }^{3}$ Policies that influence growth in income of selected population subgroups and measures that increase aggregate investment and facilitate acquisition of assets by the poor might thus be doubly beneficial for increase in growth and reduction in poverty. Creation and redistribution of new assets (investment) are found to have a greater impact on poverty reduction and growth than the redistribution of existing assets like land.

\footnotetext{
3 The Kuznets (1955) hypothesis postulates an inverted-U relationship between income and inequality according to which the degree of inequality would increase first and than decrease with level of income or economic growth. See also Aghion, Carol and Garrcia-Penalosa (1999) for a recent survey of new growth theories and Galor (2000) examination of the income distribution and the process of development.
} 
Most studies divide economies into developed and less developed groups in testing the Kuznets hypothesis. The heterogeneous relationship between income inequality and economic development is investigated by Savvides and Stegnos (2000). They employed a threshold regression model and perform tests for the existence of threshold levels and for the possibility of endogenous separation of the sample into two (or more) regimes distinguished by the country's levels of development. Threshold regression models have the advantages that they allow for heterogeneity in both intercepts and slopes. In testing the inverted-U hypothesis two common alternative specifications of the threshold model is considered by Savvides and Stegnos:

$$
\begin{aligned}
& G I N I_{i t}=\alpha_{0}+\alpha_{1} I N C_{i t}+\alpha_{2}\left(1 / I N C_{i t}\right)+\varepsilon_{i t} \\
& G I N I_{i t}=\beta_{0}+\beta_{1} \ln I N C_{i t}+\beta_{2}\left(\ln I N C_{i t}\right)^{2}+\varepsilon_{i t}
\end{aligned}
$$

where GINI is the income inequality measured as Gini coefficients and INC is the per capita income in the same year. The null hypothesis of a simple linear specification versus Kuznets is obtained from $H_{0}: \alpha_{2}=\beta_{2}=0$. Empirical results for 92 countries provide weak evidence on the existence of negative inequality-development relationship, but the relationship is described by a two-regimes split of the sample based on per-capita income measure of development. Chen (2003) also found inverted-U relationship between income distribution and long-run economic growth using crosscountry data but not in a short-run. The latter is important in cases like economics of transition. For instance Keane and Prasad (2002) in their analysis of the evolution of inequality in Poland and based on evidence from other transition economies argued that the transfer mechanisms including pensions, played an important role in mitigating increases in inequality and poverty during the country's transition to market economy. This observation suggests that the redistribution measures that reduce poverty can enhance economic growth during transition.

\section{REDISTRIBUTION OF GROWTH}

An establishment of the link between economic growth, inequality and poverty is not the ultimate goal, but redistribution that follows. Acemgoglu and Robinson (2000) studied the nineteenth century when development leads to increasing inequality. Inequality can induce political instability and forces a period of fundamental political reforms. Political and economic reforms lead to democratisation and to institutional changes which encourage taxation and redistribution. The latter is expected to result in a reduced inequality and also poverty. The authors argue that political redistribution reforms can be viewed as strategic decisions made by the political elite to prevent social unrest and revolution. The theory offers an explanation to the fall in inequality following redistribution policies due to democratisation in many Western economies. Acemgoglu and Robinson analysed the behaviour of income inequality in Britain, France, Germany and Sweden. Results suggest that development not necessarily induce a Kuznets curve because of lack of positive association between inequality and development or because of low degree of political mobilisation. The inequality-output relationship may also be associated with two types of non-democratic paths: an 
'autocratic disaster' with high inequality and low output like sub-Saharan Africa, and an 'East Asian Miracle' with low inequality and high output. ${ }^{4}$

Goudie and Ladd (1999) in their review of the literature are concerned with the interlinkages between relative poverty and inequality, absolute poverty and economic growth and in the way development strategies and development policies are designed. Regarding the effect of economic growth on inequality there is no clear relationship and little evidence that growth alters distribution in a systematic way. Countries with initially severe inequality of consumption and land are worse at reducing poverty probably because they achieve significantly slower economic growth. Goudie and Ladd find that the changes in mean income play the main role in changes in poverty, while high rate of growth has large impact on the absolute poverty. As pointed out earlier these countries are characterised by having poor institutions and lack well functioning taxation and redistributive systems. Economic growth can reduce urban poverty through the generation of economic opportunities and employment where municipal government has a key role to play in the process (Amis and Grant 2001). In similarity with the sectoral level, a positive relationship between inequality and growth and between political competitiveness and growth was found by Balisacan and Fuma (2003) using Philippines provincial data. This confirms the importance of institutions and redistribution channels on growth-inequality relationship at different levels within a country.

In respect with the above discussion of growth-inequality-poverty relationship, Ravallion (2001) assuming that initial inequality interacts with growth using data from 47 developing countries in 1980s and 1990s estimate the following non-linear relation:

$$
\Delta \ln G I N I_{i t} / \tau=\left(\beta_{0}+\beta_{1} \ln G I N I_{i, t-\tau}\right) \Delta \ln Y_{i t} / \tau+\varepsilon_{i t}
$$

where GINI is Gini coefficient, $Y$ is private consumption, $\Delta$ indicates year-to-year changes, $\tau$ is the time difference between two surveys, and $\varepsilon$ error term. In studying the relationship between growth, inequality and poverty, Ravallion prefers the investigations based on micro-empirical work on growth and distributional change to identify effective growth oriented policies. Outcomes of policy measure are heterogeneous in their impacts on different income groups. Depending on the initial position of the poor and diversity of impacts the poor might gain more from redistribution, but also suffer more from economic contraction compared to the rich.

In regards with heterogeneity in impacts in an earlier study Ravallion (1998) shows that aggregation can bias conventional tests of negative relationship between inequality and growth. The household and country level regressions are illustrated with 6651 farmhouseholds panel data for 1985-1990 from rural China. The results indicate that asset

\footnotetext{
${ }^{4}$ The working mechanism of how government policies were able to reduce poverty and inequality through economic growth in East Asia is discussed by Kakwani and Krongkaew (2000) in an introduction to a collection of studies on the relationship between rapid reduction in poverty and income disparities alongside with high economic growth in the region. For analysis of income distribution and growth in East Asia see also You (1998) and Warr (2000) who analysis of poverty incidence and economic growth and the impact of the 1997 economic crisis in South East Asia. It should be noted that the development has not been uniform. For example, in the case of China, regional and sectoral disparities in inequality have increased (Khan and Riskin 2001). Shari (2000) link the post 1990s increasing trends in income inequality in Malaysia to the government policy reversal towards liberalisation, deregulation and privatisation.
} 
inequality in the area of residence affects negatively on the consumption growth. The effect is lost in an aggregate level like in regional growth models. Bigsten, Kebede, Shimeles and Taddesse (2003) also in their analysis of growth and poverty reduction in Ethiopia during the period of economic recovery, covering 1994-97, identify several group-specific determinant factors of escaping from poverty. A decomposition of changes in poverty into growth and redistribution components indicates that potential reduction of poverty is due to the increase in real per capita income was to some extent counteracted by worsening income distribution.

In two recent collections of essays on the issues of growth, inequality and poverty (See van der Hoeven and Shorrocks 2003; and Shorrocks and van der Hoeven 2004) aggregate growth is seen as both necessary and sufficient for reducing poverty, but the concern is that benefits of growth is not evenly distributed at the national level across different population subgroups, sectors and regions. Thus in the analysis the consequences of growth for poverty, the level and distributional impacts of growth needs to be taken into account. The overall conclusion pointed out the need for diverse strategies towards growth-poverty-inequality. Initial conditions, institutions, specific country structures, and time horizons all play a specific role in the creation of national solutions to the problem of poverty and in their contributions to the achievement of globally adopted poverty reduction targets.

\section{INEQUALITY EFFECTS ON GROWTH AND DEVELOPMENT.}

Bigsten and Levin (2000) in their review of the literature deals with the relationships between economic growth, income distribution, and poverty did not find any systematic patterns of changes in income distribution during recent decades or any links from fast growth to increasing inequality. However, recent evidence tended to confirm the negative impact of inequality on growth. Recently Forbes (2000) challenges the current belief on the negative relationship between inequality and growth for 45 countries observed during 1966-1995. She uses panel data techniques and control for timeinvariant country-specific effects reduces the omitted variable bias. Results using various estimation methods show that in short and medium term, an increase in income inequality has a significant positive relationship with subsequent economic growth. Sensitivity analysis indicates that the positive relationship is robust across samples, variable definitions, and model specifications.

Quah (2001) addresses several questions in the study of economic growth and income inequality. How quantitatively important is the relation? Why should that relation matter? The findings indicate that only under conceivably high increases in inequality, would economic growth not benefit the poor. Improvements in living standard overwhelm any deterioration due to increases in income inequality. Other forces through their impacts on aggregate growth affect the poor - independently of the effect of inequality effect on economic growth. Furthermore, the uses of Gini coefficient might not reflect the true nature of inequality. Quah (2002) focus on the growth and inequality in China and India. These two countries account for a third of the world's population. The growth and inequality variables are modelled as components of a joint stochastic process, where impacts of each on different welfare indicators and personal income distribution across the joint population calibrated. Results show that the two key issues: if inequality causes growth, and if growth is disadvantageous to the poor, neither 
is empirically tenable. Economic growth benefits the poor and the mechanism where inequality causes growth is empirically irrelevant for determining the outcomes of individual income distributions. On particular importance are how growth is distributed and its impacts on poverty. In relation with human development and economic growth Ravallion (1997b) find the biggest problem facing the world's poor is not low-quality growth but too little growth. There is no sign of systematic effects of growth on inequality (Ravallion 1995). However, a higher initial inequality affects negatively in reducing poverty. Inequality can be sufficiently high to result in rising poverty despite good underlying growth prospects (Ravallion 1997a).

In examining the income distribution and the process of development Galor (2000) present a model that encompasses the transition between income inequality and the process of development. The focus is on the conflicting viewpoint about the effects of inequality on growth in the classical and the modern approaches of physical and human capital accumulations. In the classical approach inequality stimulate capital accumulation and growth, while in the modern approach equality stimulates investment in human capital and economic growth. No empirical example is given to illustrate the performance of the model. Moav (2002) demonstrates that initial income inequality persists and, provided that initial average income is above some threshold, inequality negatively affects investment on human capital and output in the long run.

\section{WAGE INEQUALITY}

There are a number of studies focusing on the impact of globalisation, economic openness, import competition from low-wage developing countries, and technical change biased to skilled labour on wage inequality in industrialised countries. The results indicate a widening of wage differentials in favour of skilled labour and highincome earners in USA and UK during recent two decades. This suggests a positive association between openness and wage inequality in industrialised economies. Borjas (1994 and 1999) finds immigration of unskilled labour to US, import competition and unskilled labour-saving technical change to explain the widening wage differential for unskilled workers in US.

With regards to the above wage differential explanations to inequality Atkinson (1999) shows that the world is working in a more complex ways than the simple unemployment, technological and trade liberalisation explanations of inequality and its trend. He refers to changes in social norms away from redistributive pay norm to one where market forces dominate the wage settings generating in turn wage inequality. Progressive income taxation and social transfers can offset rising income inequality arisen from the market place wage settings and unemployment across for instance OECD countries (Atkinson 2000). Social transfers may also change the size of dependent population through withdrawal from the labour force with increasing impact on inequality.

For the developing countries the increased demand for unskilled labour relative to skilled labour following increased openness to trade is expected to reduce wage inequality by narrowing the wage gap between skilled and unskilled workers. Empirical results (Wood 1997) show the validity of this view in the case of East Asia in 1970s and 1980s but the experience of Latin America points out the contrary in 1980s and early 1990s. The contradicting results are explained by the shift in more skilled-labour 
intensive production in Latin America as a result of entrance of China in the world market and the advent of technological change biased against unskilled labour. Differences between the two regions and two periods may explain the different experiences. The critics of globalisation point to the fact that growth may have an antipoor effect, emphasising the role of policy and institutions to promote pro-poor distribution of growth (See van der Hoeven and Shorrocks 2003).

Wage inequality patterns can differ among industrialised countries. Wage inequality has increased less in Europe than in USA and UK for the same period (Linder and Williamson 2001). The non-uniform increase in inequality among industrialised countries suggests that policy matter. Atkinson (1999) finds rising inequality not necessarily inevitable. This is in contrast to the widely held belief that it is an unavoidable consequence of the present revolution in information and communication technology or the globalisation of trade and finance. Government redistributive policy measures counteract the rise in market income inequality. The two most popular explanations for these differential trends are that: the relative supply of skills increased faster in Europe, and that European labour market institutions prevented increasing inequality.

Aghion (2002) argue that Schumpeterian Growth Theory, in which growth is driven by a sequence of quality-improving innovations, can provide explanations to the observed increases in between and within educational groups wage inequality in developing countries. Concerning the between skill groups inequality, Gottschalk (1997) finds that the rise in price of skill being a result of both an increase in the real wages paid to more skilled workers and also a decline in the absolute real wages paid to the less skilled workers leaving mean wages unchanged. In the case of Russia, Fan, Overland and Spagat (1999) find Russia having both much human capital and an education system that produces the wrong skills for a market economy. They suggest educational restructuring in Russia's transition strategy to lay groundwork for the future prosperity, better return to education and reduced inequality. In the context of South Africa Khan (1999) found that sectoral growth and skill acquisition can alleviate poverty for the black African population. Shupp (2002) suggest redistributive taxes to offset limited capital mobility between high and low-income regions to promote income growth and income equality. Lusting, Arias and Rigolini (2002) emphasis public (economic and social) policies needed to achieve simultaneously increase economic growth and reduce poverty in Latin America given its scarce fiscal resources. Ravallion and Datt (2000) using state level data derive a state-specific measure of how pro-poor economic growth ${ }^{5}$ has been in India 1960-1994. They argue that the inter-state differences in the impact of a given rate of non-farm economic growth on consumption poverty reflect systematic differences in initial conditions. The importance of initial conditions is emphasised in Van der Hoeven and Shorrocks (2003) collection of essays among others on the role of growth in poverty reduction.

Acemoglu (2002) finds two traditional explanations above not providing an entirely satisfactory explanation. A third explanation is that the relative demand for skilled labour increased differently across countries. Creation of wage compression and encouragement of more investment in technologies increased the productivity of less-

\footnotetext{
${ }^{5}$ For measurement of the rate of pro-poor growth by the mean growth rate of the poor, defined as the rate of change in the Watts index of poverty normalised by the headcount index, and examples using data from China see Ravallion and Chen (2003).
} 
skilled workers, implying less skilled biased technical change in Europe than in the US. An increase in the rate of (ability-biased) technological progress raises returns to ability and generates an increase in wage inequality between and within skill groups, increase in education attainment, and possibly a transitory productivity slowdown (Galor and Moav 2000).

\section{OTHER CONTRIBUTING FACTORS TO INEQUALITY}

Several other factors than those discussed above like growth and openness for given policy affect the inequality both at the national and global levels. Acemoglu and Ventura (2002) offers an alternative framework to the new classical growth model for analysing the world income distribution. They show that even in the absence of diminishing returns in production and technological spillovers, international trade based on specialisation leads to a stable world income distribution. Specialisation in trade reduces prices and marginal product of capital and introduces diminishing returns. The dispersion of the world income distribution is determined by the forces that shape the strength of the effects of terms of trade, namely the degree of openness to international trade and the extent of specialisation. Empirical results using data from 79 countries for 1965-1985 suggests that the above mechanism could be important in understanding cross-country differences in income levels.

In an econometric approach Calderon and Chong (2001) using a panel of countries for the period 1960 to 1995 show that the intensity of capital controls, the exchange rate, the type of exports, and the volume of trade affect the long-run distribution of income. The result is consistent with Hecksher-Ohlin hypothesis of the link between trade and wage inequality. The export of primary goods from developing countries increases their inequality, while manufacturing exports from developed countries decreases inequality. Regression results based on the data from 73 countries show that liberalisation through its impacts on wages increases inequality (Cornia and Kiiski 2001). Al-Marhubi (1997) finds developing countries with greater inequality have higher mean inflation. Inflation is found to be lower in countries that are more open to trade and stable.

A number of studies show links from the impact of globalisation, immigration, economic openness, import competition, labour-saving technical change biased to skilled labour and unemployment among the unskilled on wage inequality in industrialised countries. Wage differential has been in the favour of skilled labour. Inequality is found to be an unavoidable consequence of the information technology (IT) or globalisation of trade and finance. However, wage inequality can be offset by government redistributive policies of progressive taxes and transfers. Micro data based studies show evidence of presence of permanent and transitory wage inequality. They find a positive relationship between initial earnings and subsequent earnings growth indicating divergent in earnings over the working career. Education, gender, marital status and race are the main factors contributing to earnings inequality. 


\section{THE RELATIONSHI BETWEEN GROWTH AND INEQUALITY BASED ON THE WIID DATABASE}

\section{Model specification}

The aim in this section is twofold. First, we investigate trends in inequality and presence of relationship between growth and inequality. Second, in testing the Kuznets inverted$\mathrm{U}$ hypothesis we apply a modified version of the two alternative linear and reciprocal unconditional specifications (equations 3 and 4) of the inequality growth relationship frequently used in the literature written as:

$$
\begin{aligned}
G I N I_{i t}= & \alpha_{0}+\alpha_{1} I N C_{i t}+\alpha_{2}\left(1 / I N C_{i t}\right)+\sum_{j} \alpha_{j} X_{j i t}+\sum_{m} \alpha_{m} Z_{m i t} \\
& +\lambda_{t}+\mu_{r}+\varepsilon_{i t} \\
G I N I_{i t}= & \beta_{0}+\beta_{1} \ln I N C_{i t}+\beta_{2}\left(\ln I N C_{i t}\right)^{2}+\sum_{j} \beta_{j} \ln X_{j i t}+\sum_{m} \beta_{m} Z_{m i t} \\
& +\lambda_{t}+\mu_{r}+\varepsilon_{i t}
\end{aligned}
$$

where GINI is the average (of multiple observations) income inequality represented by Gini coefficient. The specification here is conditional, where INC is the real per capita GDP, $X_{j i t}$ is a vector of $j$ other determinant variables like education, openness and population associated with country $i$ in period $t, Z$ is $m$ vector of data characteristics, and $\lambda_{t}$ and $\mu_{r}$ are unobservable time-specific and regional-specific effects. The conditional versus unconditional versions of the model can jointly or individually be tested, $H_{0}: \alpha_{j}=0$ and $H_{0}: \beta_{j}=0$, using F-test based on residual sum of squares, by setting the coefficient of conditioning variables equal to zero.

\section{Data sources}

The data used here are obtained from several sources. One main source is the WIDER World Income Inequality Database (WIID) which is an expanded version of the Deininger and Squire (1996) database. WIID contains information on income inequality, income shares, and a number of variables indicating the source of data, and quality classification for 146 existing industrialised, developing and transition countries observed on an irregular basis mainly covering the period post 1950 until $1998^{6}$. In the regression analysis we control for several characteristic variables like income concept, data source, and reference units. The Gini coefficient is measured in percentage points. The income type indicates whether inequality is defined based on expenditure or income. A dummy variable indicates whether the data originates from Deininger and Squire data set or WIDER extension. The reference variable includes family, household or persons as reference unit.

Education as a measure of human capital is a major variable that we control for in the specification of conditional growth inequality relationship. Most widely used of such data are obtained from Barro and Lee (1996) database. This second source of our data provides information on education only at the five years intervals for the years 19601995. Education is measured as the average number of schooling years for population above the age of 15 .

\footnotetext{
${ }^{6}$ The WIID data contains 151 countries. The number of countries in our analysis differs due to the disintegration of Russia, Czechoslovakia, Yugoslavia, and reunification of Germany.
} 
The Penn World Tables (PWT) is a third data source used in our growth and income inequality study. It is also known as the Summers and Heston (1991) data. PWT provides information on international trade, GDP growth and population. Openness is measured as the ratio import plus export to the GDP produced. GDP is measured as real GDP per capita and population is defined in millions.

The unobservable time-specific effects $\left(\lambda_{t}\right)$ are represented by time dummies capturing the 10-years decennial period effects and alternatively by a time trend starting from the first year of observation, 1867, and its square. Since several countries are observed each only one period, instead of unobservable country-specific effects we estimate regionalspecific $\left(\mu_{r}\right)$ effects. The later implies that we control for unobserved between regional heterogeneity in income inequality, but we do not account for the within regional unobserved variations. The model is aimed at estimating global trends but yet account for regional heterogeneity in the levels of income inequality.

A summary statistics of the data is presented on Table 1. The mean Gini coefficient is 38.1 per cent with a standard deviation of 10.6 per cent. The range varies in the interval 15.9 (Bulgaria 1965) and 79.5 (Zambia 1970) per cent. The dispersion in real GDP per capita (0.77) and openness (0.79) relative to sample mean is much higher than that of income inequality (0.28). The numbers in parentheses are the coefficient of variation, i.e. the ratio of standard deviation and mean values of respective variable. The highest concentration of the variables is in the period 1960-1998. About 30 per cent of the data observations are from the West European countries, while 20 per cent from Latin American countries. Only 11.9 per cent of observations are based on the consumption data, remaining part are based on income data. The reference unit is mainly household (42.3 per cent) or persons (33.7 per cent).

Correlation coefficients among the key determinants of inequality are given in Table 2. The simple correlation matrix shows that inequality is declining over time, but income, level of education and trade openness are increasing over time. Income inequality is negatively related with mean income, level of education and openness. Openness and education are increasing with mean income.

\section{Estimation results}

Several models based on equations 6 and 7 are estimated assuming fixed effects model and the results are reported in Table 3. In Model A1, all slope coefficients are assumed to be zero. This specification choice was made for two reasons. One, to show that large share of variations in the Gini coefficient can be captured by introduction of time and regional dummies. Second, the three data sets are not fully overlapping as the macro variables are missing for several countries. The use of macro variables, many of which are missing, resulted in reducing the sample size from 1631 to 1108 observations. It is to be noted that Model A1 is not nested to the remaining five models as time is modelled as 10-years period dummies. In comparison with a trend the period dummy variables has the advantage that they capture decennial fluctuations in income inequality. ${ }^{7}$

\footnotetext{
${ }^{7}$ At what point of the time a time trend starts has major impact on the estimated time effect. It is very common that in the case of unbalanced cross-section of time-series data to allow the global trend to start at the first year a unit is observed. In the WIID case 1867 is assigned 1. Another alternative is to allow for individual trends where the starting point of the trend is the year a country enters the sample. This has the
} 
The estimated results are reported in Table 3 shows that the relative explanatory power of the macro variables compared to the regional and time heterogeneity effects is small. Despite the small impacts, various tests indicate that the explanatory variables should be accounted for. Model A2 is the first alternative specification of the equation 7 where the period dummies replaced by a time trend and its square and explanatory macro variables are added. The Model A3 is distinguished from Model A2 by adding a number of control variables for income definition, data source and reference units. Model A4 and A5 are reciprocal counterparts of quadratic Models A2 and A3 with the difference that $\left(I N C^{2}\right)$ in equation 7 is replaced by $(1 / I N C)$ in equation 6. Model A6 is the logarithmic equivalence of Model A3, where instead of level of INC its logarithm $(\ln I N C)$ is used.

Model A1 and A2 are not nested, but Model A2 and A3 are nested. F-test based on the residual sums of squares (21.89) is in favour of A3 indicating that control variables related to the data should be included in the specification of equation 7 . In the same way another F-test (21.21) indicates that the set of control variables should be included in the specification of equation 6. Depending on the way the income variable is given (nonlogarithmic, logarithmic or reciprocal) the six models build three groups, where A1, A2 and $\mathrm{A} 3$ belong to the first group, while A4 and A5 to the second group, and A6 to the third group. The sets of models (A2 versus A4 versus A6) and (A3 versus A5 versus A6) are not nested across the groups. The within group testing results indicate that Model A3, A5 and A6, i.e. models incorporating macro variables, data characteristic variables, and controlling for time and regional effects are the preferred model specifications. ${ }^{8}$ Unfortunately due to non-nestedness of the three models, they can not easily be ranked based on some test statistics.

Performance of the models is good. The $R^{2}$ values vary in the interval 0.54 to 0.59 . In all models openness is insignificant. Only in Model A5 a higher level of education reduces inequality. An inclusion of population to control for the size of countries did not change the results much. Income definition is a major source of differences in inequality levels across countries. Inequality is on the average 7.5 per cent lower when income is measured based in consumption than income. The time dummy and time trend variables indicate that inequality is declining but at a decreasing rate (second order is positive). In comparison with the period before 1950 the 1980 decline in income inequality is most pronounced. Regional dummies show presence of significant regional heterogeneity. Sub-Saharan Africa and Latin America are identified with the highest and East Europe lowest inequality rates.

The null hypothesis of a simple linear specification versus Kuznets (added square of income or alternatively reciprocal of income) is obtained from $H_{0}: \alpha_{2}=\beta_{2}=0$. Empirical results for 93 countries after having controlled for time effects, regional effects, human capital, population, openness and various data characteristics ${ }^{9}$ provide

disadvantage that when countries are observed only one or few periods non-consecutively, the time trend behave like any other continuous variables. A third alternative is to use decennial dummy variables or specify regional specific time trends where individual countries' incomplete trends overlap each other to build a continuous trend.

${ }^{8}$ Estimation results covering all combinations of sets of income, other conditional macroeconomic, time effects and data characteristics variables is available. Due to limited spaces only few are reported here.

9 A separation of countries by measurement of income may result in biased estimates and nonrepresentative, and non-comparable samples. A comparison of paired estimates for same country and 
evidences on the existence of negative and significant inequality-development relationship. The effect is stronger when development is defined as inverse of real GDP per capita or transformed to logarithms. The Kuznets hypothesis represents a global Ushape relationship. All six models in Table 3 produce uniform indications. The weakness is however, the small sample of countries and the short time series each country observed with interruptions. Several developing countries are observed only one single period.

\section{Some sensitivity analysis}

The high and significant constant term is an indication of the inadequacy of the Models A2-A6 in describing the data. The simple Model A1 is best in describing the data. An exclusion of the regional and time effects, i.e. a specification based on only determinants of income inequality, resulted in similar sign and significance of the coefficient as those in Models A2 and A4 but somewhat higher intercept, 52.07 and 50.24 respectively. The $R^{2}$ values are about 0.26 . The source of distortion is thus the time effects. Only 1.5 per cent or 25 observations of the data are observed during the period 1867-1949.

To avoid any time distortion we have estimated the same models as in Table 3 but by excluding the period before 1950. The results are presented in Table 4. As expected the source of distortion in the trend effects and intercepts is the few observations from the period before 1950. The new intercepts in Models B1 to B5 vary in the interval 41.7 and 61.30. The intercept in Model B6 is higher, 87.6. The sign and significance of the new trend is similar, but the coefficient of the first order is much lower reducing the negative time trend elasticity from 1.69-1.98 to 0.49-0.58. All other results in Models B2 to B6 remain the same, as the early period of the data is excluded from the estimation procedure due to missing income, education, openness and population variables. A decomposition of countries by income classes or regions due to small sample size is not meaningful. The Kuznets hypothesis is again represents a global U-shape relationship. All six models in Table 4 produce uniform indications with respect to Kuznets hypothesis.

Ram (1995) has critisized the empirical studies on the Kuznets hypothesis on the ground that they employ second degree polynomials in levels or logarithms of income. This approach allows for only one turning point in the underlying relationship and is seen as inadequate in the case of industrialised countries where inequality-growth curve has doubled back after an inverted U. A non-linear mixture of quadratic and exponential functional forms is proposed. Different versions of the function have been used by Wan (2002):

$$
\begin{aligned}
G I N I_{i t}= & \left(1-\exp \left(-\beta_{1} I N C_{i t}\right)\right) \exp \left(-\beta_{2} I N C_{i t}\right)+\beta_{3} I N C_{i t}+\beta_{4} I N C_{i t}^{2}+u_{i t} \\
G I N I_{i t}= & \beta_{0}+\left(1-\exp \left(-\beta_{1} I N C_{i t}\right)\right) \exp \left(-\beta_{2} I N C_{i t}\right)+\beta_{3} \ln I N C_{i t} \\
& +\beta_{4}\left(\ln I N C_{i t}\right)^{2}+u_{i t}
\end{aligned}
$$

same period has not been possible based on the WIID data. A third and typical way to deal with differences in income definitions across countries and over time is by introducing dummy variables additively or multiplicatively. Here we employ the additive dummy variable adjustment approach. Atkinson and Brandolini (2001) prefer the alternative approach of using a data-set where the observations are as fully consistent as possible but at the high cost of significant reduction in the sample size. 


$$
G I N I_{i t}=\beta_{0}+\left(1-\exp \left(-\beta_{1} I N C_{i t}\right)\right) \exp \left(-\beta_{2} I N C_{i t}\right)+\beta_{3} I N C_{i t}+\beta_{4}\left(1 / I N C_{i t}\right)+u_{i t}
$$

Empirical results in Wan are based on 24 transition countries each observed between 1 to 24 years (202 observations in total). The data is obtained from the WIID database. Wan estimates unconditional inequality growth relationship and thereby do not control for non-income determinants of inequality, trend or data characteristics. The results do not support the proposed flexible non-linear functions 8 to 10. The Kuznets hypothesis is rejected by the data, but a first half $U$-pattern is found to be adequate for describing the growth-inequality relationship among the transition countries.

Cornia (1999) also using WIID data studied trends in income distribution in the post World War II among 77 developed, developing and transition countries. Cornia found evidence of rising inequality among 45 countries, 23 of which with U-shaped relationship, falling inequality in 16 countries, 3 with inverted U-shape, and 12 countries with no trends. Similar is the result but based on 73 countries are presented in Cornia and Kiiski (2001) and Cornia and Court (2001). Biancotti (2003) limited the sample to 67 countries observed during 1970 to 1996 to describe the evolution of polarisation of societies. The distribution of inequality appears to be slightly bimodal at the start of period, polarised in 1980s and 1990s especially in less developed countries.

A possible and probably optimal solution to test the Kuznets hypothesis at the country level is based on WIID database. The data is the aggregate to the world level using population shares of the world population in a given year as weights in the aggregation procedure. The period would cover the post World War II without interruptions in the series. However, one major problem affecting negatively the aggregation is that countries with large population like China and India are observed only a few periods. Their periodical exit and entry to the series will cause major fluctuations in the World Gini and world income series. For the issue of instability in the aggregated income and inequality series see Heshmati (2004b and 2004c). This will have implications for inverted-U shape. Despite its limitations, the aggregate data would better shed light on the U-shape nature of the inequality-growth relationship.

\section{SUMMARY AND CONCLUSIONS}

There exists a comprehensive body of literature investigating the relationship between openness, growth, inequality and poverty. In general there exists a positive relationship between openness and growth. The effect is declining over time and different in its impact on distribution of income. However, there is no indication of a systematic relationship between trade and inequality. One major shortcoming of the literature on the link between growth, openness, inequality and poverty is that the simultaneous and direction of causal relationship between these key variables has been neglected. An establishment of linkage and direction of causality will have major impacts on the relevance of results and inferences made based on such result.

The empirical findings based on large sample of countries and relatively long time period indicates presence of convergence in per capita income but divergence in income inequality. There is evidence of strong convergence among more homogenous and integrated advanced countries but also divergence among less developed countries or regions of countries and the world. The between country contribution is much higher then within country contribution to the world inequality. Democratisation in Western 
countries has led to institutional changes and changes in taxation and redistribution reducing inequality. Other paths are East Asian Miracle with low inequality and high growth, while the Sub-Saharan Africa with high inequality and low growth. There is a conflicting viewpoint about the causal effects of inequality on growth.

Empirical results on the relationship between growth, inequality and poverty, show that outcomes of policy measures are heterogeneous. Depending on the initial position of the poor and diversity of impacts the poor might gain more from redistribution, but also suffer more from economic contraction. Results based on micro data indicates that asset inequality affects negatively consumption growth and the effect usually vanishes in an aggregate level like that in regional growth models. In general it is rather difficult to measure the effects of inequality and growth on the efforts to reduce poverty in the course of economic development in developing countries. In sum economic growth benefits the poor but at the absence of effective redistribution policies it might deteriorate the income distribution. Initial conditions, institutions, specific country structures, and time horizons each play a significant role in targeting policies to make economic growth pro-poor.

Globalisation, openness and technical change have been biased to skilled labour in industrialised countries widening wage differentials suggesting positive association between openness and wage inequality. However, the pattern is seen more complex. For developing countries these changes reduce wage inequality by narrowing the wage gap between skilled and unskilled workers. The relative demand for skilled labour and wage inequality has been developed differently across countries.

Regression results based on the WIID database suggest that income inequality is declining over time. Inequality is also declining in growth of income. There is significant regional heterogeneity in the levels and development over time. The Kuznets hypothesis is representing a global U-shape relationship between inequality and growth. Similar indications are found in other studies based on the data used here. A possible solution to the Kuznets hypothesis at the country level would be to aggregate the data to the world level using population shares as weights. However, entry and exit of countries with large population affects stability of the inequality and development series and regression results. The period should ideally cover the post World War II with less or no interruptions in the time series. 


\section{REFERENCES}

Acemoglu D. (2002), Cross-country inequality trends, NBER Working Paper No. 8832.

Acemoglu D. and J.A. Robinson (2000), Why did the west extended the franchise? Democracy, inequality, and growth in historical perspective, The Quarterly Journal of Economics CXV, 1167-1199.

Acemoglu D. and J. Ventura (2002), The world income distribution, Quarterly Journal of Economics CXVII(2), 659-694.

Addison T. and A. Heshmati (2003), The new global determinants of FDI to developing countries, Research in Banking and Finance, forthcoming.

Aghion P. (2002), Schumpeterian growth theory and the dynamics of income inequality, Econometrica 70(3), 855-882.

Aghion P., E. Carol and C. Garcia-Penalosa (1999), Inequality and economic growth: the perspective of the new growth theories, Journal of Economic Literature XXXVII, 1615-1660

Al-Marhubi F. (1997), A note on the link between income inequality and inflation, Economics Letters 55, 317-319.

Alesina A. and D. Rodrik (1994), Distributive politics and economic growth, Quarterly Journal of Economics 109, 465-490.

Amis P. and U. Grant (2001), Urban economic growth, civic management and poverty reduction, Journal of International Development 13, 997-1002.

Atkinson A.B. (1999), Is rising inequality inevitable? A critique of the transatlantic consensus, The United Nations University, WIDER Annual Lectures 3, Helsinki: UNU/WIDER.

Atkinson A.B. (2000), Increased income inequality in OECD countries and the redistributive impact of the Government budget, WIDER Working Papers 2000/202, Helsinki: UNU/WIDER.

Atkinson A.B. and A. Brandolini (2001), Promise and pitfalls in the use of "secondary" data-sets: income inequality in OECD countries as a case study, Journal Economic Literature 39, 771-799.

Balisacan A.M. and N. Fuwa (2003), Growth, inequality and politics revisited: a developing-country, Economics Letters 79, 53-58.

Barro R.J. (1991), Economic growth in a cross section of countries, Quarterly Journal of Economics 106, 406-443.

Barro R.J. (1997), Determinants of economic growth: a cross-country empirical study, MIT press, Cambridge, MA.

Barro R.J. and J-W Lee (1996), International measures of schooling years and schooling quality, American Economic Review 86(2), 218-223.

Barro R.J. and X. Sala-i-Martin (1991), Convergence across states and regions, Brookings Papers on Economic Activity 1, 107-182.

Barro R.J. and X. Sala-i-Martin (1995), Economic Growth, McGraw-Hill Inc. 
Benhabib J. and A. Rustichini (1996), Social conflict and growth, Journal of Economic Growth 1, 125-142.

Bernard A.B. and S.N. Durlauf (1996), Interpreting tests of the convergence hypothesis, Journal of Econometrics 71, 161-173.

Bernard A.B. and C.I. Jones (1996), Productivity across industries and countries: time series theory and evidence, Review of Economics \& Statistics 78(1), 135-146.

Biancotti C. (2003), A polarization of polarization? The distribution of inequality 19701996, Bank of Italy.

Bigsten A., B. Kebebe, A. Shimeles and M. Taddesse (2003), Growth and poverty reduction in Ethiopia: evidence from household panel surveys, World Development 31,1, 87-106.

Bigsten A. and J. Levin (2000), Growth, income distribution and poverty: a review, Department of Economics, Göteborg University, Working Paper in Economics No. 2000:32.

Borjas G.J. (1994), The economics of immigration, Journal of Economic Literature 31 December, 1667-1717.

Borjas G.J. (1999), Economic research on the determinants of immigration: lessons for the European Union, World Bank Technical Paper No. 438.

Bourguignon F. and C. Morrisson (2002), Inequality among world citizens: 1820-1992, American Economic Reviews 92(4), 727-747.

Calderon C. and A. Chong (2001), External sector and income inequality in interdependent economics using a dynamic panel data approach, Economics Letters 71, 225-231.

Carree M. and L. Klomp (1997), Testing the convergence hypothesis: a comment, The Review of Economics \& Statistics LXXIX(4), 683-686.

Caselli F., G. Esquivel and F. Lefort (1996), Reopening the convergence debate: a new look at cross-country growth empirics, Journal of Economic Growth 1, 363-389.

Chen B-L. (2003), An inverted-U relationship between inequality and long-run growth, Economics Letters 78, 205-212.

Cornia G.A. (1999), Liberalization, globalization and income distribution, WIDER Working Paper 1999/157, Helsinki: UNU/WIDER.

Cornia G.A. and J. Court (2001), Inequality, growth and poverty in the era of liberalization and globalization, Policy Brief No. 4, Helsinki: UNU/WIDER.

Cornia G.A. and S. Kiiski (2001), Trends in income distribution in the post WWII period: evidence and interpretation, WIDER Discussion Paper 2001/89, Helsinki: UNU/WIDER.

Deininger K. and L. Squire (1996), A new data set measuring income inequality, World Bank Economic Review 10(3), 565-591.

Deininger K. and L. Squire (1998), New ways of looking at old issues: inequality and growth, Journal of Development Economics 57, 259-287. 
Dollar D. and A. Kraay (2001a), Trade growth and poverty, Development Research Group, The World Bank.

Dollar D. and A. Kraay (2001b), Growth is good for the poor, Policy Research Working paper 2001:2199, Development Research Group, The World Bank.

Dowrick S. and J.B. DeLong (2001), Globalization and convergence, Paper for NBER Conference on Globalization in Historical Perspective, Santa Barbara, California, In: Williamson J. (ed.), Globalization in historical perspective, Chicago, University of Chicago Press, forthcoming.

Dowrick S. and D-T. Nguyen (1989), OECD comparative economic growth 1950-85: catch-up and convergence, American Economic Review 79(5), 1010-1030.

Edwards T.H. (1992), Trade orientation, distortions, and growth in developing countries, Journal of Development Economics 39(1), 31-57.

Edwards T.H. (1998), Openness, productivity and growth: what do we really know, Economic Journal 108, 383-398.

Eicher T.S. and C. Garcia-Penalosa (2001), Inequality and growth: the dual role of human capital in development, Journal of Development Economics 66, 173-197.

Epstein G.S. and U. Spiegel (2002), Natural inequality, production and economic growth, Labour Economics 8, 463-473.

Fan C.S., J. Overland and M. Spagat (1999), Human capital, growth and inequality in Russia, Journal of Comparative Economics 27(4), 618-643.

Forbes K.J. (2000), A reassessment of the relationship between inequality and growth, American Economic Review 90(4), 869-880.

Galor O. (2000), Income distribution and the process of development, European Economic Review 44, 706-712.

Galor O. and O. Moav (2000), Ability-biased technological transition, wage inequality and economic growth, the Quarterly Journal of Economics 115(2), 469-497.

Galor O. and O. Moav (2001), Evolution of growth, European Economic Review 45, 718-729.

Gholami R., S-Y. To, Lee and A. Heshmati (2003), The causal relationship between information and communication technology and foreign direct investment, WIDER Discussion Papers 2003/30, Helsinki: UNU/WIDER.

Gottschalk P. (1997), Inequality, income growth, and mobility: the basic facts, Journal of Economic Perspectives 11(2), 21-40.

Goudie A. and P. Ladd (1999), Economic growth, poverty and inequality, Journal of International Development 11, 177-195.

Heshmati A. (2000), On the causality between GDP and health care expenditure in the augmented Solow growth model, SSE/EFI Working Paper Series in Economics and Finance 2001:423.

Heshmati A. (2003), Measurement of a multidimentional index of globalization and its impact on income inequality, WIDER Discussion Paper 2003/69, Helsinki: UNU/WIDER. 
Heshmati A. (2004a), The relationship between globalisation, poverty and income inequality, IZA Discussion paper 2004:1277.

Heshmati A. (2004b), The world distribution of income and income inequality, IZA Discussion Paper 2004:1267.

Heshmati A. (2004c), Data issues and databases used in analysis of growth, poverty and economic inequality, IZA Discussion Paper 2004:1263.

Iacoviello M. (1998), Inequality Dynamics: evidence from some European countries, Working Paper No. 191, Maxwell School of Citizenship and Public Affairs, Syracuse University.

Islam N. (1995), Growth empirics: a panel data approach, The Quarterly Journal of Economics 110, 1127-1170.

Jones C.I. (2002), Introduction to economic growth, Second Edition, W.W. Norton \& Compacy.

Kakwani N. and M. Krongkaew (2000), Introduction: Economic growth, poverty and income inequality in the Asia-Pacific region, Journal of the Asia Pacific Economy 5(1/2), 9-13.

Keane M.P. and E.S Prasad (2002), Inequality, transfers and growth: new evidence from the economic transition in Poland, The Review of Economics and Statistics 84(2), 324-341.

Khan A. Haider (1999), Sectoral growth and poverty alleviation: a multiplier decomposition technique applied to South Africa, World Development 27(3), 521530 .

Khan A.R. and C. Riskin (2001), Inequality and poverty in China in the age of globalization, Oxford University Press.

Knowles S. and P.D. Owen (1997), Education and health in an effective-labour empirical growth model, The Economic Record 73(223), 314-328.

Kuznets S. (1955), Economic growth and income inequality, American Economic Review 45, 1-28.

Lee K., M.H. Pesaran and R. Smith (1997), Growth and convergence in a multi-country empirical stochastic Solow model, Journal of Applied Econometrics 12, 357-392.

Lee W. and J.E. Roemer (1999), Inequality and redistribution revisited, Economics Letters 65, 339-346.

Lichtenberg F.R. (1994), Testing the convergence hypothesis, Review of Economics \& Statistics 76(3), 576-579.

Lindert P.H. and J.G. Williamson (2001), Does globalization make the World more unequal?, NBER Working Paper 2001:8228.

Lustig N., O. Arias and J. Rigolini (2002), Poverty reduction and economic growth: a two-way causality, Inter-American Development Bank, Washington D.C., Sustainable Development Department, Technical Papers Series.

Mankiew N.G., D. Romer and D.H. Weil (1992), A contribution to the empirics of economics growth, The Quarterly Journal of Economics 107, 407-438. 
Moav O. (2002), Income distribution and macroeconomics: the persistence of inequality in a convex technology framework, Economics Letters 75, 187-192.

Nerlove M. (2000), Growth rate convergence, fact or artifact? An essay on panel data econometrics, in J. Krishnakumar and E. Ronchetti, eds., Panel Data Econometrics: Future Directions, pp. 3-34, Amsterdam: North Holland.

Perotti R. (1996), Growth, income distribution, and democracy: what the data say, Journal of Economic Growth 1(3), 149-187.

Persson T. and G. Tabellini (1994), Is inequality harmful for growth? American economic Review 84, 600-621.

Quah D. (1993), Galton's fallacy and tests of the convergence hypothesis, Scandinavian Journal of Economics 95, 427-443.

Quah D. (1996a), Twin Peaks: growth and convergence in models of distribution dynamics, The Economic Journal 106(437), 1045-1055.

Quah D. (1996b), Regional convergence clusters across Europe, European Economic Review 40, 951-958.

Quah D. (1996c), Empirics for economic growth and convergence, European Economic Review 40, 1353-1375.

Quah D. (2001), Some simple arithmetic on how income inequality and economic growth matter, Paper presented at WIDER conference on Growth and Poverty, 2526 May 2001, Helsinki.

Quah D. (2002), One third of the world's growth and inequality, Economics Department, CEPR Discussion Paper 2002:3316.

Ravallion M. (1995), Growth and poverty: evidence for developing countries in the 1980s, Economics Letters 48, 411-417.

Ravallion M. (1997a), Can high-inequality developing countries escape absolute poverty?, Economics Letters 56, 51-57.

Ravallion M. (1997b), Good and bad growth: the human development reports, World Development 25(5), 631-638.

Ravallion M. (1998), Does aggregation hide the harmful effects of inequality on growth?, Economics Letters 61, 73-77.

Ravallion M. (2001), Growth, inequality and poverty: looking beyond averages, World Development 29(11), 1803-1815.

Ravallion M. (2003), Inequality convergence, Economics Letters 80, 351-356.

Ravallion M. and S. Chen (2003), Measuring pro-poor growth, Economics Letters 78, 93-99.

Ravallion M. and G. Datt (2000), When growth is pro-poor? Evidence from the diverse experience of Indian states, World Bank Policy Research, WP 2263

Rodriguez F. and D. Rodrik (1999), Trade policy and economic growth: a skeptic's guide to the cross-national evidence, NBER 1999:7081. 
Sacks J. and A. Warner (1995), Economic reform and the process of global integration, Brookings Papers on Economic Activity 1:95.

Savvides A. and T. Stegnos (2000), Income inequality and economic development: evidence from the threshold regression model, Economics Letters 69, 207-212.

Shari I. (2000), Economic growth and income inequality in Malaysia, 1971-95, Journal of the Asia Pacific Economy 5(1/2), 112-124.

Shorrocks A. and R. van der Hoeven (2004), Eds., Growth, inequality, and poverty: Prospects for pro-poor economic development, Oxford University Press.

Shupp F.R. (2002), Growth and income inequality in South Africa, Journal of Economic Dynamics \& Control 26, 1699-1720.

Solimano A. (2001), The evolution of world income inequality: assessing the impact of globalization, Unpublished manuscript, ECLAC, CEPAL - Serie Macroeconomica del desarrollo No. 11, Santiago, Chile.

Stiglitz J.E. and Weiss (1981), Credit rationing in markets with imperfect information, American Economic Review 71(3), 393-410.

Summers R. and A. Heston (1991), The Penn World Table (Mark 5): an expanded set of international comparisons, 1950-1988, Quarterly Journal of Economics 106, 327368.

Sylwester K. (2000), Income inequality, education expenditures, and growth, Journal of Development Economics 63, 379-398.

Van der Hoeven R. and A. Shorrocks (2003), Eds., Perspectives on growth and poverty, United Nations University Press, Tokyo, Japan.

Wan G.H. (2002), Income inequality and growth in transition economies: are nonlinear models needed?, WIDER Discussion Paper 2002/104, Helsinki: UNU/WIDER.

Warr P.G. (2000), Poverty incidence and economic growth in Southeast Asia, Journal of Asian Economics 11, 431-441.

Wolff E.N. (2001), The impact of IT investment on income and wealth inequality in the Postwar US economy, Information Economics and Policy 14, 233-251.

Wood A. (1997), Openness and wage inequality in developing countries: the Latin American challenge to East Asian continental wisdom, World Bank Economic Review 11(1), 33-57.

You I. (1998), Income distribution and growth in East Asia, Journal of Development Studies 34(6), 000-000. 
Table 1. Summary statistics of the data covering the period 1867-1998.

\begin{tabular}{|c|c|c|c|c|}
\hline Variable & Mean & Std Deviation & Minimum & Maximum \\
\hline \multicolumn{5}{|l|}{ Income inequality measure: } \\
\hline GINI coefficient & 38.065 & 10.517 & 15.900 & 79.500 \\
\hline \multicolumn{5}{|c|}{ Determinants of inequality variation: } \\
\hline Population in 1000 & 70.676 & 178.889 & 0.063 & 1238.599 \\
\hline INC Real GDP / capita in 1000 & 8.418 & 6.479 & 0.539 & 33.703 \\
\hline$(1 / \mathrm{INC})$ & 0.117 & 0.014 & 0.096 & 0.159 \\
\hline Schooling year & 6.236 & 2.726 & 0.300 & 11.900 \\
\hline Openness & 59.804 & 47.511 & 3.378 & 439.029 \\
\hline Trend & 112.211 & 13.805 & 1.000 & 132.000 \\
\hline \multicolumn{5}{|l|}{ Period dummy variables: } \\
\hline Period dummy 1867-1949 & 0.015 & 0.123 & 0.000 & 1.000 \\
\hline Period dummy 1950-1959 & 0.068 & 0.252 & 0.000 & 1.000 \\
\hline Period dummy 1960-1969 & 0.158 & 0.365 & 0.000 & 1.000 \\
\hline Period dummy 1970-1979 & 0.204 & 0.403 & 0.000 & 1.000 \\
\hline Period dummy 1980-1989 & 0.271 & 0.445 & 0.000 & 1.000 \\
\hline Period dummy 1990-1998 & 0.283 & 0.451 & 0.000 & 1.000 \\
\hline \multicolumn{5}{|l|}{ Regional dummy variables: } \\
\hline Middle East \& NA & 0.035 & 0.184 & 0.000 & 1.000 \\
\hline East Asia & 0.057 & 0.232 & 0.000 & 1.000 \\
\hline South East Asia & 0.053 & 0.225 & 0.000 & 1.000 \\
\hline South Asia & 0.065 & 0.247 & 0.000 & 1.000 \\
\hline Latin America & 0.196 & 0.397 & 0.000 & 1.000 \\
\hline Sub-Saharan Africa & 0.096 & 0.295 & 0.000 & 1.000 \\
\hline East Europe & 0.117 & 0.322 & 0.000 & 1.000 \\
\hline Former USSR & 0.077 & 0.266 & 0.000 & 1.000 \\
\hline West Europe & 0.303 & 0.460 & 0.000 & 1.000 \\
\hline \multicolumn{5}{|l|}{ Income characteristic variables: } \\
\hline Expenditure & 0.119 & 0.303 & 0.000 & 1.000 \\
\hline Deininger \& Squire & 0.207 & 0.368 & 0.000 & 1.000 \\
\hline Reference Unit person & 0.337 & 0.435 & 0.000 & 1.000 \\
\hline Reference Unit family & 0.031 & 0.144 & 0.000 & 1.000 \\
\hline Reference Unit household & 0.423 & 0.439 & 0.000 & 1.000 \\
\hline \multicolumn{5}{|l|}{ Sample size: } \\
\hline Countries & 146 & 146 & 146 & 146 \\
\hline Observations & 1631 & 1631 & 1631 & 1631 \\
\hline
\end{tabular}

Source: Author's calculations. 
Table 2. Correlation matrix based on 1266-1631 observations.

\begin{tabular}{|c|c|c|c|c|c|c|}
\hline & Year & Gi ni & Popul at i on & GDP/ capi ta & School i ng & Openness \\
\hline Year of observation & 1. 0000 & & & & & \\
\hline Gi ni coef $\mathrm{fici}$ ent & $\begin{array}{r}-0.2174 \\
0.0001\end{array}$ & 1. 0000 & & & & \\
\hline Popul at i on & $\begin{array}{l}0.0274 \\
0.3168\end{array}$ & $\begin{array}{r}-0.1526 \\
0.0001\end{array}$ & 1. 0000 & & & \\
\hline Real GDP/capi ta & $\begin{array}{l}0.2209 \\
0.0001\end{array}$ & $\begin{array}{r}-0.3736 \\
0.0001\end{array}$ & $\begin{array}{r}-0.1701 \\
0.0001\end{array}$ & 1. 0000 & & \\
\hline School i ng year & $\begin{array}{l}0.3088 \\
0.0001\end{array}$ & $\begin{array}{r}-0.4512 \\
0.0001\end{array}$ & $\begin{array}{r}-0.1291 \\
0.0001\end{array}$ & $\begin{array}{l}0.8007 \\
0.0001\end{array}$ & 1. 0000 & \\
\hline Trade openness & $\begin{array}{l}0.2430 \\
0.0001 \\
\end{array}$ & $\begin{array}{r}-0.0714 \\
0.0091\end{array}$ & $\begin{array}{r}-0.2735 \\
0.0001\end{array}$ & $\begin{array}{l}0.1663 \\
0.0001\end{array}$ & $\begin{array}{l}0.1362 \\
0.0001\end{array}$ & 1. 0000 \\
\hline
\end{tabular}

Note: p-values under the coefficient.

Source: Author's calculations. 
Table 3. Least Squares parameter estimates based on WIID database for the period 1867-1998.

\begin{tabular}{|c|c|c|c|c|c|c|}
\hline Variable & Model A1 & Model A2 & Model A3 & Model A4 & Model A5 & Model A6 \\
\hline Intercept & $44.0688 \mathrm{a}$ & $229.6681 \mathrm{a}$ & $245.1354 \mathrm{a}$ & $252.2288 \mathrm{a}$ & $266.5116 \mathrm{a}$ & $114.5669 \mathrm{a}$ \\
\hline Population. & - & $-0.0044 \mathrm{a}$ & $-0.0034 \mathrm{~b}$ & $-0.0030 \mathrm{~b}$ & -0.0021 & $0.5243 \mathrm{a}$ \\
\hline INC Real GDP per capita & - & $-0.5436 \mathrm{a}$ & $-0.7281 \mathrm{a}$ & $-0.1453 c$ & $-0.3105 a$ & - \\
\hline INC squared & - & $0.0167 \mathrm{a}$ & $0.0173 \mathrm{a}$ & - & - & - \\
\hline Log INC & - & - & - & - & - & $34.2651 \mathrm{a}$ \\
\hline Log INC squared & - & - & - & - & - & $-2.0928 \mathrm{a}$ \\
\hline$(1 / \mathrm{INC})$ & - & - & - & $-6.1100 \mathrm{a}$ & $-5.7331 \mathrm{a}$ & - \\
\hline Schooling year & - & -0.0379 . & -0.1043 . & -0.2430 & $-0.3153 b$ & -0.1445 . \\
\hline Openness & - & 0.0002 & 0.0034 . & -0.0083 & -0.0048 & $0.0117 \mathrm{c}$ \\
\hline Trend & - & $-3.2454 \mathrm{a}$ & $-3.5640 \mathrm{a}$ & $-3.6340 \mathrm{a}$ & $-3.9324 \mathrm{a}$ & $-3.8646 \mathrm{a}$ \\
\hline Trend squared & - & $0.0139 \mathrm{a}$ & $0.0158 \mathrm{a}$ & $0.0157 \mathrm{a}$ & $0.0174 \mathrm{a}$ & $0.0171 \mathrm{a}$ \\
\hline Period 1867-1949 (ref.) & - & - & - & - & - & - \\
\hline Period 1950-1959 & $-2.5399 \mathrm{c}$ & - & - & - & - & - \\
\hline Period 1960-1969 & $-2.7946 c$ & - & - & - & - & - \\
\hline Period 1970-1979 & $-5.8086 \mathrm{a}$ & - & - & - & - & - \\
\hline Period 1980-1989 & $-8.5811 \mathrm{a}$ & - & - & - & - & - \\
\hline Period 1990-1998 & $-5.3881 \mathrm{a}$ & - & - & - & - & - \\
\hline Middle East \& NA (ref.) & - & - & - & - & - & - \\
\hline East Asia & $-4.5831 \mathrm{a}$ & $-5.3064 \mathrm{a}$ & $-8.0888 \mathrm{a}$ & $-4.3574 \mathrm{a}$ & $-7.0852 \mathrm{a}$ & $-9.3478 \mathrm{a}$ \\
\hline South East Asia & $4.7841 \mathrm{a}$ & $3.6691 \mathrm{a}$ & $2.5844 \mathrm{~b}$ & $5.4374 \mathrm{a}$ & $4.2761 \mathrm{a}$ & $2.7013 \mathrm{~b}$ \\
\hline South Asia & $-1.9537 \mathrm{c}$ & $-3.5111 b$ & $-3.5108 \mathrm{a}$ & -0.5655 & -0.6958 & $-1 . .9240$. \\
\hline Latin America & $9.0524 \mathrm{a}$ & $9.0032 \mathrm{a}$ & $7.0798 \mathrm{a}$ & $8.8382 \mathrm{a}$ & $6.9065 \mathrm{a}$ & $6.8819 \mathrm{a}$ \\
\hline Sub-Saharan Africa & $10.4370 \mathrm{a}$ & $9.9279 \mathrm{a}$ & $10.1091 \mathrm{a}$ & $13.9514 \mathrm{a}$ & $13.8762 \mathrm{a}$ & $14.1010 \mathrm{a}$ \\
\hline East Europe & $-11.9413 \mathrm{a}$ & $-11.4039 \mathrm{a}$ & $-13.4341 \mathrm{a}$ & $-11.5202 \mathrm{a}$ & $-13.5994 \mathrm{a}$ & $-14.1916 \mathrm{a}$ \\
\hline Former USSR & $-5.8159 \mathrm{a}$ & $-5.9334 \mathrm{~b}$ & $-8.7905 \mathrm{a}$ & $-5.5244 \mathrm{~b}$ & $-8.3842 \mathrm{a}$ & $-9.1869 \mathrm{a}$ \\
\hline West Europe & $-3.8103 a$ & $-3.4707 \mathrm{a}$ & $-3.6181 \mathrm{a}$ & $-3.8972 \mathrm{a}$ & $-4.0739 a$ & $-3.5435 \mathrm{a}$ \\
\hline Expenditure & - & - & $-7.5041 \mathrm{a}$ & - & $-7.3493 \mathrm{a}$ & $-7.8753 a$ \\
\hline Deininger \& Squire data & - & - & $-1.1856 \mathrm{c}$ & - & $-1.1134 \mathrm{c}$ & -0.8210 \\
\hline Reference Unit person & - & - & - & - & - & - \\
\hline Reference Unit family & - & - & 1.9374. & - & $2.4465 \mathrm{c}$ & 2.1556 . \\
\hline Ref. Unit household & - & - & 0.2575 . & - & 0.0070 . & 0.0634 . \\
\hline \multicolumn{7}{|c|}{ Income and trend elasticities: } \\
\hline Average trend effect & - & $-1.6857 \mathrm{a}$ & $-1.7911 \mathrm{a}$ & $-1.8723 \mathrm{a}$ & $-1.9799 \mathrm{a}$ & $-1.9458 \mathrm{a}$ \\
\hline Average income effect & - & $-0.4030 \mathrm{a}$ & $-0.5825 \mathrm{a}$ & $-0.8602 \mathrm{~b}$ & $-0.9813 \mathrm{a}$ & $-2.0047 \mathrm{a}$ \\
\hline \multicolumn{7}{|l|}{ Model performance: } \\
\hline Adjusted R square & 0.5352 & 0.5583 & 0.5896 & 0.5641 & 0.5942 & 0.5992 \\
\hline F-value & $145.350 \mathrm{a}$ & $94.3000 \mathrm{a}$ & $84.7100 \mathrm{a}$ & $96.5400 \mathrm{a}$ & $86.3200 \mathrm{a}$ & $88.0900 \mathrm{a}$ \\
\hline RMSE & 7.1701 & 6.8294 & 6.5830 & 6.7841 & 6.5460 & 6.5061 \\
\hline \multicolumn{7}{|l|}{ Sample size: } \\
\hline Countries & 146 & 93 & 93 & 93 & 93 & 93 \\
\hline Periods & $1-53$ & $1-53$ & $1-53$ & $1-53$ & $1-53$ & $1-53$ \\
\hline Observations & 1631 & 1108 & 1108 & 1108 & 1108 & 1108 \\
\hline
\end{tabular}

Note: Significant at the less than 1\% (a), 1-5\% (b), 5-10\% (c) and above 10\% (.) levels of significance. Source: Author's calculations. 
Table 4. Least Squares parameter estimates based on WIID database for the period 1950-1998.

\begin{tabular}{|c|c|c|c|c|c|c|}
\hline Variable & Model B1 & Model B2 & Model B3 & Model B4 & Model B5 & Model B6 \\
\hline Intercept & $41.7078 \mathrm{a}$ & $57.0564 \mathrm{a}$ & $58.9424 \mathrm{a}$ & $59.5472 \mathrm{a}$ & $61.2997 \mathrm{a}$ & $87.6331 \mathrm{a}$ \\
\hline Population. & - & $-0.0044 \mathrm{a}$ & $-0.0034 b$ & $-0.0030 \mathrm{~b}$ & -0.0021 & $0.5243 \mathrm{a}$ \\
\hline INC Real GDP per capita & - & $-0.5436 \mathrm{a}$ & $-0.7281 \mathrm{a}$ & $-0.1453 \mathrm{c}$ & $-0.3105 \mathrm{a}$ & - \\
\hline INC squared & - & $0.0167 \mathrm{a}$ & $0.0173 \mathrm{a}$ & - & - & - \\
\hline $\log I N C$ & - & - & - & - & - & $34.2651 \mathrm{a}$ \\
\hline Log INC squared & - & - & - & - & - & $-2.0928 \mathrm{a}$ \\
\hline$(1 / \mathrm{INC})$ & - & - & - & $-6.1100 \mathrm{a}$ & $-5.7331 \mathrm{a}$ & - \\
\hline Schooling year & - & -0.0379. & -0.1043. & -0.2430 & $-0.3153 b$ & -0.1445 \\
\hline Openness & - & 0.0002 & 0.0034 & -0.0083 & -0.0048 & $0.0117 \mathrm{c}$ \\
\hline Trend & - & $-0.9646 \mathrm{a}$ & $-0.9773 \mathrm{a}$ & $-1.0656 \mathrm{a}$ & $-1.0727 \mathrm{a}$ & $-1.0671 \mathrm{a}$ \\
\hline Trend squared & - & $0.0139 \mathrm{a}$ & $0.0158 \mathrm{a}$ & $0.0157 \mathrm{a}$ & $0.0174 \mathrm{a}$ & $0.0171 \mathrm{a}$ \\
\hline Period 1950-1959 (ref.) & - & - & - & - & - & - \\
\hline Period 1960-1969 & -0.1445 & - & - & - & - & - \\
\hline Period 1970-1979 & $-3.1520 \mathrm{a}$ & - & - & - & - & - \\
\hline Period 1980-1989 & $-5.9254 \mathrm{a}$ & - & - & - & - & - \\
\hline Period 1990-1998 & $-2.7351 \mathrm{a}$ & - & - & - & - & - \\
\hline Middle East \& NA (ref.) & - & - & - & - & - & - \\
\hline East Asia & $-4.8690 \mathrm{a}$ & $-5.3064 \mathrm{a}$ & $-8.0888 \mathrm{a}$ & $-4.3574 \mathrm{a}$ & $-7.0852 \mathrm{a}$ & $-9.3478 \mathrm{a}$ \\
\hline South East Asia & $4.4972 \mathrm{a}$ & $3.6691 \mathrm{a}$ & $2.5844 \mathrm{~b}$ & $5.4374 \mathrm{a}$ & $4.2761 \mathrm{a}$ & $2.7013 \mathrm{~b}$ \\
\hline South Asia & $-2.2336 c$ & $-3.5111 b$ & $-3.5108 \mathrm{a}$ & -0.5655 & -0.6958 & -1.9240 \\
\hline Latin America & $8.8006 \mathrm{a}$ & $9.0032 \mathrm{a}$ & $7.0798 \mathrm{a}$ & $8.8382 \mathrm{a}$ & $6.9065 \mathrm{a}$ & $6.8819 \mathrm{a}$ \\
\hline Sub-Saharan Africa & $10.0981 \mathrm{a}$ & $9.9279 \mathrm{a}$ & $10.1091 \mathrm{a}$ & $13.9514 \mathrm{a}$ & $13.8762 \mathrm{a}$ & $14.1010 \mathrm{a}$ \\
\hline East Europe & $-12.2307 \mathrm{a}$ & $-11.4039 a$ & $-13.4341 \mathrm{a}$ & $-11.5202 \mathrm{a}$ & $-13.5994 \mathrm{a}$ & $-14.1916 \mathrm{a}$ \\
\hline Former USSR & $-6.1091 \mathrm{a}$ & $-5.9334 \mathrm{~b}$ & $-8.7905 \mathrm{a}$ & $-5.5244 b$ & $-8.3842 \mathrm{a}$ & $-9.1869 \mathrm{a}$ \\
\hline West Europe & $-4.1572 \mathrm{a}$ & $-3.4707 \mathrm{a}$ & $-3.6181 \mathrm{a}$ & $-3.8972 \mathrm{a}$ & $-4.0739 \mathrm{a}$ & $-3.5435 \mathrm{a}$ \\
\hline Expenditure & - & - & $-7.5041 \mathrm{a}$ & - & $-7.3493 \mathrm{a}$ & $-7.8753 a$ \\
\hline Deininger \& Squire data & - & - & $-1.1856 \mathrm{c}$ & - & $-1.1134 \mathrm{c}$ & -0.8210 \\
\hline Reference Unit person & - & - & - & - & - & - \\
\hline Reference Unit family & - & - & 1.9374. & - & $2.4465 \mathrm{c}$ & 2.1566 \\
\hline Ref. Unit household & - & - & 0.2575 . & - & 0.0070 . & 0.0634 \\
\hline \multicolumn{7}{|c|}{ Income and trend elasticities: } \\
\hline Average trend effect & - & $-0.5344 \mathrm{a}$ & $-0.4883 \mathrm{a}$ & $-0.5797 \mathrm{a}$ & $-0.5342 \mathrm{a}$ & $-0.5379 a$ \\
\hline Average income effect & - & $-0.4030 \mathrm{a}$ & $-0.5825 \mathrm{a}$ & $-0.8602 \mathrm{~b}$ & $-0.9813 \mathrm{a}$ & $-2.0048 \mathrm{a}$ \\
\hline \multicolumn{7}{|l|}{ Model performance: } \\
\hline Adjusted R square & 0.5343 & 0.5583 & 0.5896 & 0.5641 & 0.5942 & 0.5992 \\
\hline F-value & $154.4700 \mathrm{a}$ & $94.3000 \mathrm{a}$ & $84.7100 \mathrm{a}$ & $96.5400 \mathrm{a}$ & $86.3200 \mathrm{a}$ & $88.0900 \mathrm{a}$ \\
\hline RMSE & 7.1687 & 6.8294 & 6.5830 & 6.7841 & 6.5460 & 6.5061 \\
\hline \multicolumn{7}{|l|}{ Sample size: } \\
\hline Countries & 146 & 93 & 93 & 93 & 93 & 93 \\
\hline Periods & $1-49$ & $1-49$ & $1-49$ & $1-49$ & $1-49$ & $1-49$ \\
\hline Observations & 1605 & 1108 & 1108 & 1108 & 1108 & 1108 \\
\hline
\end{tabular}

Note: Significant at the less than $1 \%$ (a), $1-5 \%$ (b), 5-10\% (c) and above $10 \%$ (.) levels of significance.

Source: Author's calculations. 